\title{
Pembelajaran Kontekstual Melalui Penggunaan Multimedia Interaktif Model Simulasi untuk Meningkatkan Aktivitas dan Hasil Belajar dalam Pembelajaran Bahasa Indonesia di Kelas XI SMK Negeri 9 Garut Tahun 2014-2015.
}

\author{
Teti Nur Aini \\ Sekolah Tinggi Keguruan dan Ilmu Pendidikan (STKIP) Garut, Indonesia \\ Email: tetinuraini69@gmail.com
}

\begin{abstract}
One of the problems in learning Indonesian is the low activity and student learning outcomes. As an alternative to overcome these problems is by contextual learning through the use of interactive multimedia simulation model in Indonesian language learning. According to Hull's and Sounders (Komalasari, 2010: 6) "In contextual learning, students find meaningful connections between abstract ideas and practical application in real-world contexts. Students internalize the concept through discovery, reinforcement, and connectedness. "In addition, according to Sanjaya (2012: 206-210), the functions and benefits of using instructional media are" ... to: 1) capture a particular object or event; 2) manipulate certain circumstances, events, or objects; 3 ) increase the students' passion and motivation; 4) learning media has practical value ... ". Thus, the application of the above learning model allows for an increase in student activity and learning outcomes.
\end{abstract}

Key Word: Contextual Learning Through Interactive Multimedia Usage Simulation Model, Learning Activity, Learning Outcomes.

Abstrak - Salah satu permasalahan dalam pembelajaran Bahasa Indonesia adalah rendahnya aktivitas dan hasil belajar siswa. Sebagai salah satu alternatif untuk mengatasi permasalahan tersebut adalah dengan pembelajaran kontekstual melalui penggunaan multimedia interaktif model simulasi dalam pembelajaran bahasa Indonesia. Menurut Hull's dan Sounders (Komalasari, 2010: 6) "Di dalam pembelajaran kontekstual, siswa menemukan hubungan penuh makna antara ide-ide abstrak dengan penerapan praktis di dalam konteks dunia nyata. Siswa menginternalisasi konsep melalui penemuan, penguatan, dan keterhubungan." Selain itu, menurut Sanjaya (2012: 206-210) fungsi dan manfaat penggunaan media pembelajaran antara lain adalah “....berperan untuk: 1) menangkap suatu objek atau peristiwa-peristiwa tertentu; 2) memanipulasi keadaan, peristiwa, atau objek tertentu; 3) menambah gairah dan motivasi belajar siswa; 4) media pembelajaran memiliki nilai praktis...". Dengan demikian, penerapan model pembelajaran di atas memungkinkan adanya peningkatan aktivitas dan hasil belajar siswa.

Kata kunci: Pembelajaran Kontekstual Melalui Penggunaan Multimedia Interaktif Model Simulasi, Aktivitas Belajar, Hasil Belajar. 


\section{PENDAHULUAN}

PP No. 19 Tahun 2005, Bab I Pasal 1 Ayat 6 merupakan petunjuk bagi guru dalam melaksanakan pengelolaan proses pembelajaran. Guru memiliki peranan penting baik dalam tahap memahami perencanaan program pendidikan, pengelolaan pembelajaran, maupun tahap evaluasi hasil pembelajaran.

Tugas atau peranan guru adalah mengatur lingkungan dan kondisi yang memungkinkan siswa dapat belajar. Sebagai seorang desainer pembelajaran yang baik, guru mempunyai banyak pilihan dalam menentukan strategi pembelajaran yang tepat. Salah satu strategi pembelajaran yang layak dipertimbangkan adalah strategi pembelajaran kontektual (Contextual Teaching and Learning).

Komalasari (2010:7) menjelaskan bahwa "Pembelajaran kontekstual merupakan pendekatan pembelajaran yang digunakan pendidik atau guru dengan cara mengaitkan antara materi yang dipelajari dengan kehidupan nyata siswa sehari-hari, baik dalam lingkungan keluarga, sekolah, masyarakat maupun warga Negara, dengan tujuan untuk menemukan makna materi tersebut bagi kehidupannya."

Multimedia interaktif model simulasi merupakan bagian dari penerapan teknologi dalam upaya memecahkan permasalahan dalam pembelajaran. Model simulasi pada dasarnya merupakan salah satu strategi pembelajaran yang bertujuan memberikan pengalaman belajar yang lebih konkret melalui penciptaan tiruan-tiruan bentuk pengalaman yang mendekati suasana sebenarnya. Media ini digunakan dalam kegiatan pembelajaran dengan melibatkan pendengaran dan penglihatan sekaligus dalam satu proses atau kegiatan. Media tersebut efektif digunakan para pendidik saat ini dengan tujuan membantu dalam menyelesaikan kesulitan belajar.

Penelitian yang penulis lakukan ini bertujuan untuk mengetahui kualitas aktivitas belajar siswa, hasil belajar siswa, dan tanggapan siswa pada saat dan setelah mengikuti pembelajaran kontekstual melalui penggunaan multimedia interaktif model simulasi untuk meningkatkan hasil belajar dalam pembelajaran Bahasa Indonesia.

Ilustrasi hubungan variabel-variabel pada penelitian ini adalah sebagai berikut.

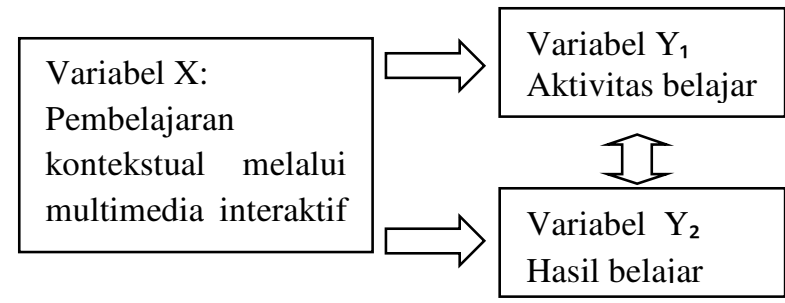

Gambar 1. Ilustrasi hubungan variabelvariabel

Lokasi penelitian ini dilaksanakan di SMK Negeri 9, Kabupaten Garut pada kelas XI Tahun Pelajaran 2014/2015. Dari populasi kelas XI yang berjumlah 12 kelas, kelas yang penulis pilih sebagai sampel penelitian eksperimen (yang diberi perlakuan) adalah kelas XI TGB 2. Pengambilan sampel di atas dipilih berdasarkan asumsi bahwa kemampuan siswa relatif sama (homogen).

Pada penelitian ini peneliti berupaya menerapkan model pembelajaran kontekstual melalui penggunaan multimedia interaktif model simulasi untuk meningkatkan hasil belajar dalam pembelajaran Bahasa Indonesia. Pembelajaran kontekstual merupakan pendekatan pembelajaran yang digunakan pendidik atau guru dengan cara mengaitkan antara materi yang dipelajari dengan kehidupan nyata siswa sehari-hari, baik dalam lingkungan keluarga, sekolah, masyarakat maupun warga Negara, dengan tujuan untuk menemukan makna materi tersebut bagi kehidupannya. Komalasari (2010) menyebutkan bahwa "Model pembelajaran ini didesain untuk memfasilitasi siswa menginternalisasi konsep melalui penemuan, penguatan, dan keterhubungan. 
Pembelajaran kontekstual menghendaki kerja dalam sebuah tim, baik di kelas, laboratorium, tempat bekerja maupun bank. Pembelajaran kontekstual menuntut guru mendesain lingkungan belajar yang merupakan gabungan beberapa bentuk pengalaman untuk mencapai hasil yang diinginkan.

$$
\text { Menurut Asyhar (2011: 45) }
$$

"multimedia interaktif model simulasi adalah jenis media yang digunakan dalam kegiatan pembelajaran dengan memberikan tiruan-tiruan nyata atau percontohanpercontohan yang lebih real mengenai proses pembelajaran yang dijalani.“

Aktivitas belajar siswa adalah suatu organisme yang hidup. Dalam dirinya terkandung banyak kemungkinan dan potensi yang hidup dan sedang berkembang. Dalam diri masing-masing siswa tersebut terdapat prinsip aktif yaitu keinginan berbuat dan bekerja sendiri. Prinsip aktif mengendalikan tingkah lakunya (Hamalik: 89).

Hasil belajar adalah pola-pola perbuatan, nilai-nilai, pengertianpengertian, sikap-sikap, apresiasi dan keterampilan. Hasil belajar adalah perubahan perilaku secara keseluruhan bukan hanya salah satu aspek potensi kemanusiaan saja, artinya hasil pembelajaran yang dikategorisasi oleh pakar pendidikan sebagaimana tersebut di atas tidak dilihat secara fragmentaris atau terpisah melainkan komprehensif (Suprijono, 2010).

\section{HASIL DAN PEMBAHASAN}

Sesuai dengan rumusan masalah dan tujuan penelitian yang telah dituliskan pada bagian sebelumnya, maka pada bagian ini dibahas mengenai: 1) kualitas aktivitas belajar siswa pada saat mengikuti pembelajaran kontekstual melalui penggunaan multimedia interaktif model simulasi untuk meningkatkan hasil belajar dalam pembelajaran Bahasa Indonesia, dan 2) hasil belajar siswa setelah mengikuti pembelajaran kontekstual melalui penggunaan multimedia interaktif model simulasi untuk meningkatkan hasil belajar dalam pembelajaran Bahasa Indonesia.

Uraian hasil dan pembahasan tentang 1) kualitas aktivitas belajar siswa pada saat mengikuti pembelajaran kontekstual melalui penggunaan multimedia interaktif model simulasi untuk meningkatkan hasil belajar dalam pembelajaran bahasa Indonesia dilengkapi dengan (a) penilaian efektivitas perencanaan pembelajaran kontekstual melalui penggunaan multimedia interaktif model simulasi untuk meningkatkan aktivitas dan hasil belajar, dan (b) efektivitas pelaksanaan pembelajaran kontekstual melalui penggunaan multimedia interaktif model simulasi untuk meningkatkan aktivitas dan hasil belajar. Sementara itu, hasil dan pembahasan tentang 2) hasil belajar siswa setelah mengikuti pembelajaran kontekstual melalui penggunaan multimedia interaktif model simulasi untuk meningkatkan hasil belajar dalam pembelajaran bahasa Indonesia dilengkapi dengan (a) peningkatan hasil belajar yang signifikan dengan menggunakan pembelajaran kontekstual melalui penggunaan multimedia interaktif model simulasi. Uraian terakhir, yaitu 3) deskripsi tanggapan siswa terhadap pembelajaran kontekstual melalui penggunaan multimedia interaktif model simulasi dalam pembelajaran bahasa Indonesia.

Berdasarkan hasil temuan penelitian dan hasil analisis, serta pengujian data, diperoleh hal-hal sebagai berikut.

1. Kualitas aktivitas siswa pada saat mengikuti pembelajaran kontekstual melalui penggunaan multimedia interaktif model simulasi untuk meningkatkan hasil belajar dalam pembelajaran Bahasa Indonesia

a. Penilaian efektivitas perencanaan pembelajaran kontekstual melalui penggunaan multimedia interaktif model simulasi untuk meningkatkan aktivitas 
dan hasil belajar dalam pembelajaran Bahasa Indonesia

Berdasarkan hasil penilaian observer, kemampuan peneliti dalam perencanaan pembelajaran kontekstual melalui penggunaan multimedia interaktif model simulasi untuk meningkatkan aktivitas dan hasil belajar dalam pembelajaran Bahasa Indonesia sudah lengkap pada aspek penulisan: 1) Identitas Mata Pelajaran, 2) Perumusan Indikator, 3) Perumusan Tujuan Pembelajaran, 4) Pemilihan Materi Ajar, hanya saja pada aspek kesesuaian dengan karakteristik peserta didik belum lengkap dan harus ditingkatkan, 5) Pemilihan Sumber Belajar, aspek kesesuaian dengan karakteristik peserta didik belum lengkap dan harus ditingkatkan, 6) Pemilihan Media Belajar, 7) Metode Pembelajaran, aspek kesesuaian dengan karakteristik peserta didik belum lengkap dan harus ditingkatkan; 8) Skenario Pembelajaran, aspek menampilkan kegiatan pendahuluan, inti, dan penutup dengan jelas dan aspek kesesuaian dengan metode pembelajaran belum lengkap dan harus ditingkatkan, dan 9) Rancangan Penilaian Otentik.

b. Aktivitas belajar siswa pada saat mengikuti pembelajaran kontekstual melalui penggunaan multimedia interaktif model simulasi untuk meningkatkan hasil belajar dalam pembelajaran Bahasa Indonesia

Berdasarkan analisis hasil penelitian terhadap aktivitas siswa selama mengikuti pembelajaran kontekstual melalui penggunaan multimedia interaktif model simulasi untuk meningkatkan hasil belajar siswa dalam pembelajaran Bahasa Indonesia ini dapat disimpulkan bahwa sebagian besar siswa telah menunjukkan aktivitas yang baik dan kondusif selama mengikuti kegiatan pembelajaran. Hal tersebut terlihat dalam hasil pengamatan yang menunjukkan bahwa sebagian besar yaitu $79 \%$ aktivitas siswa berada pada kategori sangat sering, sering, dan cukup.
Sementara itu 21\% aktivitas siswa yaitu aktivitas mengajukan pertanyaan selama kegiatan pembelajaran, menjawab pertanyaan guru maupun teman, dan memberi saran, komentar, atau tanggapan masih terdapat siswa yang berkategori jarang dalam melakukan aktivitas tersebut. Dengan demikian, dapat disimpulkan bahwa aktivitas belajar siswa menunjukkan peningkatan yang baik apabila dibandingkan dengan aktivitas belajar mereka sebelum diadakannya kegiatan penelitian ini.

c. Efektivitas pelaksanaan pembelajaran kontekstual melalui penggunaan multimedia interaktif model simulasi untuk meningkatkan aktivitas belajar dalam pembelajaran Bahasa Indonesia

Berdasarkan penilaian observer ke-1 dan ke-2, pelaksanaan pembelajaran kontekstual melalui penggunaan multimedia interaktif model simulasi untuk meningkatkan aktivitas belajar dalam pembelajaran Bahasa Indonesia pada umumnya sudah berjalan dengan baik dan amat baik, mulai dari kegiatan: 1) pendahuluan (Apersepsi dan Motivasi), 2) Penyampaian kompetensi dan rencana kegiatan, 3) Kegiatan Inti (Penguasaan materi pembelajaran, Penerapan strategi pembelajaran yang mendidik, Pemanfaatan sumber belajar/media dalam pembelajaran, Pelaksanaan Penilaian Autentik, Pelibatan peserta didik dalam pembelajaran, Penggunaan bahasa yang benar dan tepat dalam pembelajaran), dan 4) Penutup pembelajaran.

Berdasarkan hasil pengamatan dapat disimpulkan bahwa pelaksanaan pembelajaran kontekstual melalui penggunaan multimedia interaktif model simulasi untuk meningkatkan aktivitas dalam pembelajaran Bahasa Indonesia dapat dikategorikan efektif. Hal tersebut ditunjukkan dengan presentasi yang tinggi yaitu sebesar $92 \%$ untuk sebagian besar aspek pelaksanaan pembelajaran berkategori baik dan amat baik, hanya $8 \%$ 
dari aspek pelaksanaan pembelajaran masih berkategori cukup.

2. Hasil belajar siswa setelah mengikuti pembelajaran kontekstual melalui penggunaan multimedia interaktif model simulasi untuk meningkatkan hasil belajar dalam pembelajaran Bahasa Indonesia

Berdasarkan hasil penelitian diketahui bahwa rata-rata/mean dari kemampuan awal sebelum dilakukan penelitian sebesar 34,38 dari skor ideal 100. Nilai terkecilnya 5 dan terbesarnya 50 serta simpangan baku sebesar 13,777. Hal ini menunjukkan bahwa kemampuan awal siswa masih tergolong rendah. Setelah pembelajaran menggunakan pemanfaatan multimedia interaktif model simulasi rataratanya mengalami kenaikan menjadi 75,42 dengan nilai terkecilnya 40 dan terbesarnya 95 serta simpangan baku sebesar 14,059.

Dilihat dari sebaran data hasil belajar akhir, diketahui bahwa hasil belajar siswa tersebar dari nilai 40 sampai dengan 95, kebanyakkan siswa yang mempunyai nilai hasil belajar sebesar 75 yaitu sebanyak $33,3 \%$.

Berdasarkan pengamatan terhadap efektivitas pembelajaran dengan pemanfaatan multimedia interaktif model simulasi diketahui bahwa sebagian besar siswa yang mengikuti pembelajaran dengan pemanfaatan multimedia interaktif model simulasi mengalami ketuntasan sebanyak $79,2 \%$ serta hanya $20,8 \%$ siswa yang belum tuntas. Dengan demikian, ketuntasan yang dicapai lebih dari $75 \%$ sehingga peneliti dapat mengambil kesimpulan bahwa: "Pembelajaran dengan pemanfaatan multimedia interaktif model simulasi efektif dilakukan pada pembelajaran Bahasa Indonesia di SMKN 9 Garut".

a. Peningkatan hasil belajar yang signifikan dengan menggunakan pembelajaran kontekstual melalui penggunaan multimedia interaktif model simulasi
Perhitungan peningkatan hasil belajar dilakukan dengan menggunakan Gain ternormalisasi. Gain ternormalisasi diperoleh dari hasil bagi antara selisih nilai postes dan pretes, dengan selisih nilai ideal dan nilai pretes.

Hasil pengamatan menunjukkan bahwa nilai Gain ternormalisasi yang paling kecil adalah 0,27 dan paling besar 0,90. Berdasarkan interpretasi Gain ternormalisasi, kategori peningkatan hasil belajar tersebut tersebar mulai dari tingkat rendah sampai tingkat tinggi.

Setelah dilakukan pengolahan data diketahui bahwa rata-rata / mean dari Gain ternormalisasi sebesar 0,6367. Dengan merujuk pada interpretasi Gain ternormalisasi, hal tersebut tergolong sedang. Adapun nilai terkecilnya adalah 0,27 tergolong kategori sedang dan terbesarnya 0,90 termasuk kategori tinggi. sebagian besar siswa mengalami peningkatan hasil belajar termasuk kategori sedang dan tinggi yaitu masing-masing sebanyak $45,8 \%$ dan $41,7 \%$, serta sisanya tergolong peningkatan rendah sebanyak $12,5 \%$.

Uji sebaran data atau uji normalitas data dilakukan dengan menggunakan uji Shapiro-Wilk. Hasil pengujian tersebut menghasilkan nilai sig untuk sebaran data tes awal dan tes akhir berturut-turut sebesar 0,015 dan 0,004, sedangkan nilai $\alpha$ yang digunakan sebesar 0,05. Dengan demikian, nilai sig dari kedua kelas tersebut lebih kecil dari $\alpha$. Berdasarkan kondisi tersebut, dapat disimpulkan bahwa sebaran data hasil belajar siswa tidak berdistribusi normal.

Hasil uji normalitas data di atas menunjukkan bahwa sebaran data tidak berdistribusi normal, sehingga untuk pengujian hipotesis uji dua rata-rata digunakan uji statistika nonparametrik, dalam hal ini menggunakan uji Wilcoxon. Hasil pengujian dengan Wilcoxon menunjukkan bahwa seluruh siswa mengalami peningkatan hasil belajar. Hal 
ini ditunjukkan dengan seluruh siswa memiliki nilai tes akhir lebih besar dari nilai tes awalnya.

Dari hasil pengujian uji Wilcoxon terhadap perbedaan hasil belajar antara sebelum dan sesudah menggunakan pembelajaran kontekstual melalui penggunaan multimedia interaktif model simulasi diperoleh nilai $\mathrm{z}=-4,301$ dengan nilai Asymp. Sig. (2 tailed) sebesar 0,000, sedangkan nilai $\alpha$ yang digunakan sebesar 0,05 dan nilai $z_{\text {tabel }}=1,96$. Dengan demikian, dapat dikatakan bahwa nilai sig $<\alpha$ atau nilai zhitung $\leq-Z_{\text {tabel }}$ yaitu $-4,301<-$ 1,96. Berdasarkan kondisi tersebut, dapat disimpulkan bahwa "Terdapat peningkatan hasil belajar yang signifikan antara sebelum dan sesudah menggunakan pembelajaran kontekstual melalui penggunaan multimedia interaktif model simulasi".

\section{Tanggapan siswa terhadap pembelajaran kontekstual melalui penggunaan multimedia interaktif model simulasi untuk meningkatkan hasil belajar dalam pembelajaran Bahasa Indonesia}

$$
\text { Pengumpulan data untuk }
$$

mengetahui tanggapan siswa dalam penelitian ini dilakukan dengan cara menyebarkan angket. Data yang diperoleh kemudian diolah dengan menggunakan teknik presentase dengan bentuk pernyataan positif. Masing-masing jawaban dikaitkan secara kuantitatif dengan ketentuan $\mathrm{SS}=5, \mathrm{~S}=4, \mathrm{KS}=3$, $\mathrm{TS}=2$, dan $\mathrm{STS}=1$.

Berdasarkan analisis hasil penelitian terhadap aktivitas siswa selama mengikuti pembelajaran kontekstual melalui penggunaan multimedia interaktif model simulasi untuk meningkatkan hasil belajar siswa dalam pembelajaran Bahasa Indonesia ini dapat disimpulkan bahwa sebagian besar siswa telah menunjukkan aktivitas yang baik dan kondusif selama mengikuti kegiatan pembelajaran. Hal tersebut terlihat dalam hasil pengamatan yang menunjukkan bahwa sebagian besar yaitu $79 \%$ aktivitas siswa berada pada kategori sangat sering, sering, dan cukup. Sementara itu $21 \%$ aktivitas siswa yaitu aktivitas mengajukan pertanyaan selama kegiatan pembelajaran, menjawab pertanyaan guru maupun teman, dan memberi saran, komentar, atau tanggapan masih terdapat siswa yang berkategori jarang dalam melakukan aktivitas tersebut. Dengan demikian, dapat disimpulkan bahwa aktivitas belajar siswa menunjukkan peningkatan yang baik apabila dibandingkan dengan aktivitas belajar mereka sebelum diadakannya kegiatan penelitian ini.

\section{KESIMPULAN}

Berdasarkan hasil temuan penelitian dan analisis data, peneliti dapat menyimpulkan hal-hal sebagai berikut. 1) Perencanaan pembelajaran kontekstual melalui penggunaan multimedia interaktif model simulasi untuk meningkatkan aktivitas dan hasil belajar dalam pembelajaran bahasa Indonesia sudah terkategori sangat lengkap dan lengkap. RPP ini terkategori baik karena $87 \%$ dari komponennya sudah berkategori sudah lengkap dan lengkap, dengan demikian RPP ini efektif untuk digunakan dalam kegiatan penelitian pembelajaran kontekstual melalui penggunaan multimedia interaktif model simulasi untuk meningkatkan aktivitas dan hasil belajar siswa dalam pembelajaran Bahasa Indonesia. 2) Aktivitas siswa selama mengikuti pembelajaran kontekstual melalui penggunaan multimedia interaktif model simulasi untuk meningkatkan hasil belajar siswa dalam pembelajaran Bahasa Indonesia telah menunjukkan aktivitas yang baik dan kondusif karena 79\% aktivitas siswa berada pada kategori sangat sering, sering, dan cukup, sementara itu 21\% aktivitas siswa berkategori jarang. 3) Pelaksanaan pembelajaran kontekstual melalui penggunaan multimedia interaktif 
model simulasi untuk meningkatkan aktivitas dalam pembelajaran Bahasa Indonesia dapat dikategorikan efektif. Hal tersebut ditunjukkan dengan presentasi yang tinggi yaitu sebesar $92 \%$ untuk sebagian besar aspek pelaksanaan pembelajaran berkategori baik dan amat baik. Sedangkan hanya $8 \%$ dari aspek pelaksanaan pembelajaran masih berkategori cukup. 4) Sebagian besar siswa yang mengikuti pembelajaran dengan pemanfaatan multimedia interaktif model simulasi mengalami ketuntasan sebanyak $79,2 \%$ serta hanya $20,8 \%$ siswa yang belum tuntas. Dengan demikian, ketuntasan yang dicapai lebih dari $75 \%$. berdasarkan hal tersebut, pembelajaran kontekstual melalui penggunaan multimedia interaktif model simulasi efektif dilakukan pada pembelajaran Bahasa Indonesia di SMKN 9 Garut. 5) Peningkatan hasil belajar tersebar mulai dari tingkat rendah sampai tingkat tinggi. Sebagian besar siswa mengalami peningkatan hasil belajar termasuk kategori sedang dan tinggi yaitu sebanyak 45,8\% dan $41,7 \%$, serta sisanya tergolong peningkatan rendah sebanyak $12,5 \%$. Pengujian Wilcoxon menunjukkan bahwa terdapat peningkatan hasil belajar yang signifikan antara sebelum dan sesudah menggunakan pembelajaran kontekstual melalui penggunaan multimedia interaktif model simulasi.

Berdasarkan hasil temuan tersebut, peneliti merekomendasikan hal-hal sebagai berikut: 1) Perlu upaya peningkatan kompetensi guru terkait dengan pengembangan model pembelajaran sehingga dapat tercipta kegiatan pembelajaran yang lebih bervariasi dan lebih menarik. 2) Perlu upaya peningkatan kompetensi guru terkait dengan perancangan multimedia pembelajaran sehingga di masa depan pemanfaatannya dapat memberikan hasil yang maksimal terutama pada materi pembelajaran yang bersifat abstrak dan sulit untuk dipelajari. 3) Perlu upaya sekolah dan institusi yang terkait untuk melengkapi sarana dan prasarana pembelajaran berbasis komputer di sekolah-sekolah agar di masa depan kegiatan pembelajaran dapat memanfaatkan produk teknologi tersebut secara maksimal.

\section{DAFTAR PUSTAKA}

[1] Amri, Sofan, dan Iif Khoiru Ahmadi. 2010. Proses Pembelajaran Kreatif dan Inovatif dalam Kelas. Jakarta: PT Prestasi Pustakaraya.

[2] Ariani, Niken dan Dany Haryanto. 2010. Pembelajaran multimedia di Sekolah

(Pedoman Pembelajaran interaktif, Konstruktif , dan Prospektif). Jakarta: Prestasi Pustaka.

[3] Arifin, Z. 2009. Cermat Berbahasa Indonesia untuk Perguruan Tinggi. Jakarta: CV Akademika Pressindo, Konstruktif , dan Prospektif). Jakarta: Prestasi Pustaka.

[4] Arikunto, Suharsimi. 2013. Dasardasar Evaluasi Pendidikan, Edisi 2. Jakarta: Bumi Aksara.

[5] Asyhar, H. Rayndra. 2011. Kreatif Mengembangkan Media Pembelajaran. Jakarta: Gaung Persada.

[6] Darmawan, Deni. 2012. Teknologi Pembelajaran. Bandung: PT Remaja Rosdakarya

[7] Hamalik, Oemar. 1994. Media Pendidikan. Bandung: PT Citra Aditya Bakti.

[8] Hamalik, Oemar. 2010. Proses Belajar Mengajar. Jakarta: PT Bumi Aksara.

[9] Komalasari, K. 2010. Pembelajaran Kontekstual Konsep dan Aplikasi. Bandung: PT Refika Aditama.

[10] Kementrian Pendidikan dan Kebudayaan Republik Indonesia. 2014. Buku Guru Bahasa Indonesia Ekspresi diri dan Akademik SMA/MA/SMK/MAK Kelas XI. 
Jakarta: Kementrian Pendidikan dan Kebudayaan.

[11] Kementrian Pendidikan dan Kebudayaan Republik Indonesia. 2014. Bahasa Indonesia Ekspresi diri dan Akademik SMA/MA/SMK/MAK Kelas XI Semester 2. Jakarta: Kementrian Pendidikan dan Kebudayaan.

[12] Kementrian Pendidikan dan Kebudayaan Republik Indonesia. 2014. Materi Pelatihan Guru Implementasi Kurikulum 2013 Tahun ajaran 2014/2015. Jakarta: Kementrian Pendidikan dan Kebudayaan.

[13] M., Sardiman A. 2007. Interaksi dan Motivasi Belajar Mengajar. Jakarta: PT Raja Grafindo Persada.

[14] Majid, Abdul. 2013. Strategi Pembelajaran. Bandung: PT Remaja Rosdakarya.

[15] Munir. 2009. Pembelajaran Jarak Jauh Berbasis Teknologi Informasi dan Komunikasi, Cetakan kesatu. Bandung: CV Alfabeta.

[16] Mulyasa, E. 2008. Menjadi Guru Profesional. Bandung: PT Remaja Rosdakarya.

Riduwan. 2010. Belajar Mudah Penelitian untuk Guru, Karyawan, dan Peneliti Pemula, Cetakan Keenam. Bandung: CV Alfabeta.

[18] Rusijono \& Mustaji. 2008. Penelitian teknologi Pembelajaran. Surabaya: Unesa University Press.

[19] Sanjaya, Wina. 2012. Strategi Pembelajaran Berorientasi Standar Proses Pendidikan. Jakarta: Kencana Prenada Media Group.

[20] Sanjaya, Wina. 2012. Perencanaan dan Desain Sistem instruksional. Jakarta: Kencana Prenada Media Group.

[21] Sardiman,Tabrani Rusyan, Zaenal Arifin, Toto Fathoni. 2004. Ilmu
Pendidikan. Bandung: Ramadja Karya.

[22] Slameto. 2003. Belajar dan Faktorfaktor yang Mempengaruhinya. Jakarta: PT Rineka Cipta.

[23] Sudjana, Nana. 2009. Dasar-dasar Proses Belajar Mengajar. Bandung: Sinar Baru Algesindo

[24] Sugiyono. 2010. Metodologi Penelitian Pendidikan Pendekatan Kuantitatif, Kualitatif, dan $R \& D$. Bandung Alfabeta.

[25] Suherman, dkk. 2000. Evaluasi dan Pembelajaran Matematika. Bandung: JICA.

[26] Sukmadinata, Nana Syaodih. 2012. Metode Penelitian Pendidikan. Bandung: PT Remaja Rosdakarya.

[27] Sundayana, Rostina. 2013. Statistika Penelitian Pendidikan. Bandung: Alfabeta.

[28] Supriyono. 2009. Cooperative Learning,Teori dan Aplikasi Paikem. Yogyakarta: Pustaka Belajar.

[29] Surya, Moh. 2003. Psikologi Pembelajaran . Bandung: Bany Quraisy.

[30] Undang-undang Sistem pendidikan Nasional. Nasution. 2012. Teknologi Pendid

[31] Warsita, Bambang. 2008. Teknologi Pembelajaran Landasan \& Aplikasinya. Jakarta:PT Rineka Cipta.

[32] Subrata,H. 2009. Keterampilan Menulis. (online). Tersedia: http://mbahbrata-edubolgspot.com/2010/03/keterampilan -menulis.html.diupload pada Juli 2015

[33] Sudrajat, Akhmad . Strategi belajar Mengajar. (http://www.psb-psmaorg) diuplod pada Juli 2015. 
p-ISSN : 2460-7363

e-ISSN : 2614-6606 